Young, A. H., Goodwn,, G. M., Dick, H., et al (1994) Effects of glucocorticoids on 5- $\mathrm{HT}_{1 \mathrm{~A}}$ presynaptic function in the mouse. Psychopharmacology, 114, 360-365.

Psychopharmacology Research Unit

A. H. Young

Littlemore Hospital

Oxford OX4 4XN

\section{Seizures and antidepressants}

SIR: Curran (BJP, March 1994, 164, 421) states that "Amitriptyline and fluoxetine ... are both associated with a greater propensity to cause seizures in susceptible patients". While it is correct that fluoxetine should be avoided in patients with unstable epilepsy, this does not distinguish fluoxetine from other antidepressants, as Curran's letter suggests.

Maprotoline accounts for $29.9 \%$ of the reports to the Committee on the Safety of Medicines of convulsions during treatment with antidepressants, mianserin $17.3 \%$, fluvoxamine $6.1 \%$ and fluoxetine $2.3 \%$. Amitriptyline accounts for $6.8 \%$ of the total reports (Edwards \& Wheel, 1992). Figures such as these highlight the need to be cautious in prescribing any psychotropic medication to a patient who has epilepsy or is otherwise at risk of seizures.

Curran is incorrect in suggesting that fluoxetine is more likely to induce seizures than other selective serotonin reuptake inhibitors. The letter used as evidence for this statement (Ware \& Stewart, 1989) reports a single patient whose electroencephalogram revealed epileptiform activity before starting fluoxetine. A comprehensive review of seizures associated with antidepressants concludes that fluoxetine has a lower seizure risk than older, tricyclic antidepressants (Rosenstein et al, 1993). Thus, it is quite inaccurate to highlight fluoxetine as particularly epileptogenic.

Edwards, J. G. \& WhEal, H. V. (1992) Assessment of epileptogenic potential: experimental, clinical and epidemiological approaches. Journal of Psychopharmacology, 6, 204-213.

WARE, M. R. \& STEWART, R. B. (1989) Seizures associated with fluoxetine therapy. DICP Annals of Pharmacotherapy, 23, 428.

Rosenstein, D. L., Nelson, J. C. \& Jacobs, S. C. (1993) Seizures associated with antidepressants: a review. Journal of Clinical Psychiatry. 54, 289-299.

\section{Lilly Industries Ltd}

Basingstoke RG21 2SY

JOANNA NAKIELNY

\section{Darier's disease cosegregating with affective disorder}

SIR: We reported a family (pedigree 324 ) in which Darier's disease, a rare autosomal dominant skin disorder, is cosegrating with major affective disorder, and postulated that a susceptibility gene for affective disorder may lie close to and in genetic linkage with the gene for Darier's disease (BJP, March 1994, 164, 355-358). We suggested that when the chromosomal location of the Darier's gene was found, markers from this region should be tested for genetic linkage with bipolar disorder.

We would like to update our report by drawing attention to some recent work of ours carried out in collaboration with colleagues at the Institute of Psychiatry in London and at the Institute for Human Genetics in Bonn.

First, we have mapped the gene for Darier's disease to chromosome 12q23-q24.1 in five British families (including pedigree 324) (Craddock et al, 1993; Parfitt et al, 1994).

Secondly, we have studied a set of highly polymorphic genetic markers from this region to test for genetic linkage in 45 families containing two or more members with bipolar disorder (excluding pedigree 324). We found modest evidence of linkage under heterogeneity using both the traditional lod score method of analysis and also non-parametric sib-pair analysis (Dawson et al, 1994). Our findings do not meet conventional levels required for statistical significance, and we recommend caution when interpreting our results. However, given that there is some a priori evidence for a susceptibility locus for bipolar disorder in this chromosomal region, we would urge other research groups to examine markers from this region in independent sets of bipolar pedigrees.

Finally, we would like to mention one change to the published genogram for pedigree 324 : during follow-up, subject 2.12, the youngest member of the sibship, has shown mild features of Darier's disease. He has not yet had an episode of affective disorder.

Craddock, N., Dawson, E., Burge, S., et al (1993) The gene for Darier's disease maps to chromosome 12q23-q24.1. Human Molecular Genetics, 2, 1941-1943.

Dawson, E., PArfit, E., Roberts, Q., et al (1994) Linkage studies of bipolar disorder in the region of the Darier's disease gene on chromosome 12q23-24.1. American Journal of Medical Genetics: Neuropsychiatric Genetics (in press).

Parfitt, E., Burge, S., Craddock, N., et al (1994) The gene for Darier's disease maps between D12S78 and D12S79. Human Molecular Genetics, 3, 35-38.

Nicholas Craddock PETER McGufFin MiChAEL OWEN

Department of Psychological Medicine

University of Wales College of Medicine Cardiff CF4 4XN 